Noticias

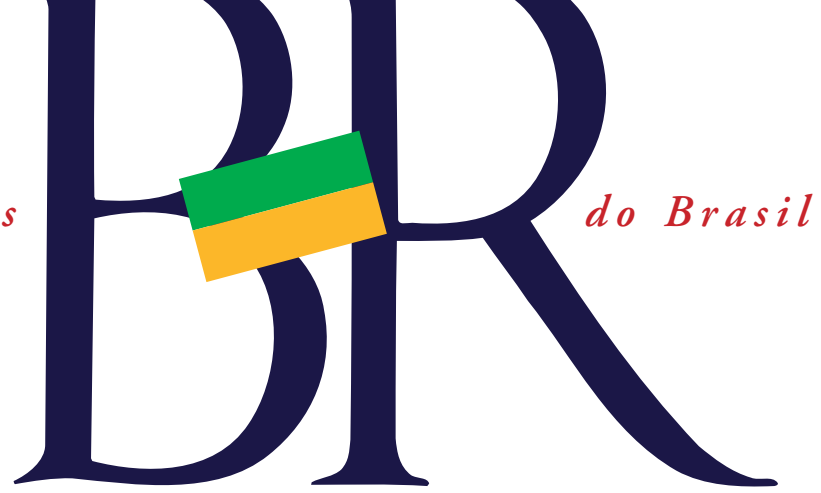

Tecnologia

\section{Desenho de embalagens diminui perdas em frutas frescas}

Por serem alimentos frágeis, altamente perecíveis, as frutas exigem cuidados especiais para diminuir o desperdício e as perdas econômicas após a colheita. Para contribuir para um processo mais sustentável desde o campo até o consumidor, pesquisadores do Instituto Nacional de Tecnologia (INT), do Instituto de Macromoléculas da Universidade Federal do Rio de Janeiro (UFRJ) e do Centro de Tecnologia de Alimentos da Embrapa (CTAA) desenvolveram caixotes dobráveis e embalagens para o transporte e exposição de frutas que aumentam em uma semana a vida dos produtos e mantêm as perdas abaixo de $10 \%$, índice similar ao de países desenvolvidos.

A ideia é simples, mas gerou o depósito de 40 patentes e demandou $\mathrm{R} \$ 7,5$ milhões do fundo tecnológico do BNDES ao longo de quatro anos de pesquisas e testes. $\mathrm{O}$ projeto poderá ajudar a diminuir o desperdício de alimentos, estimado em 26 milhões de toneladas ao ano no Brasil, dos quais $45 \%$ seriam de hortifruti. Ao invés de frutas sobrepostas e sem ventilação, as embalagens desenvolvidas permitem que as bandejas sejam empilhadas sem risco de amassar as fru-

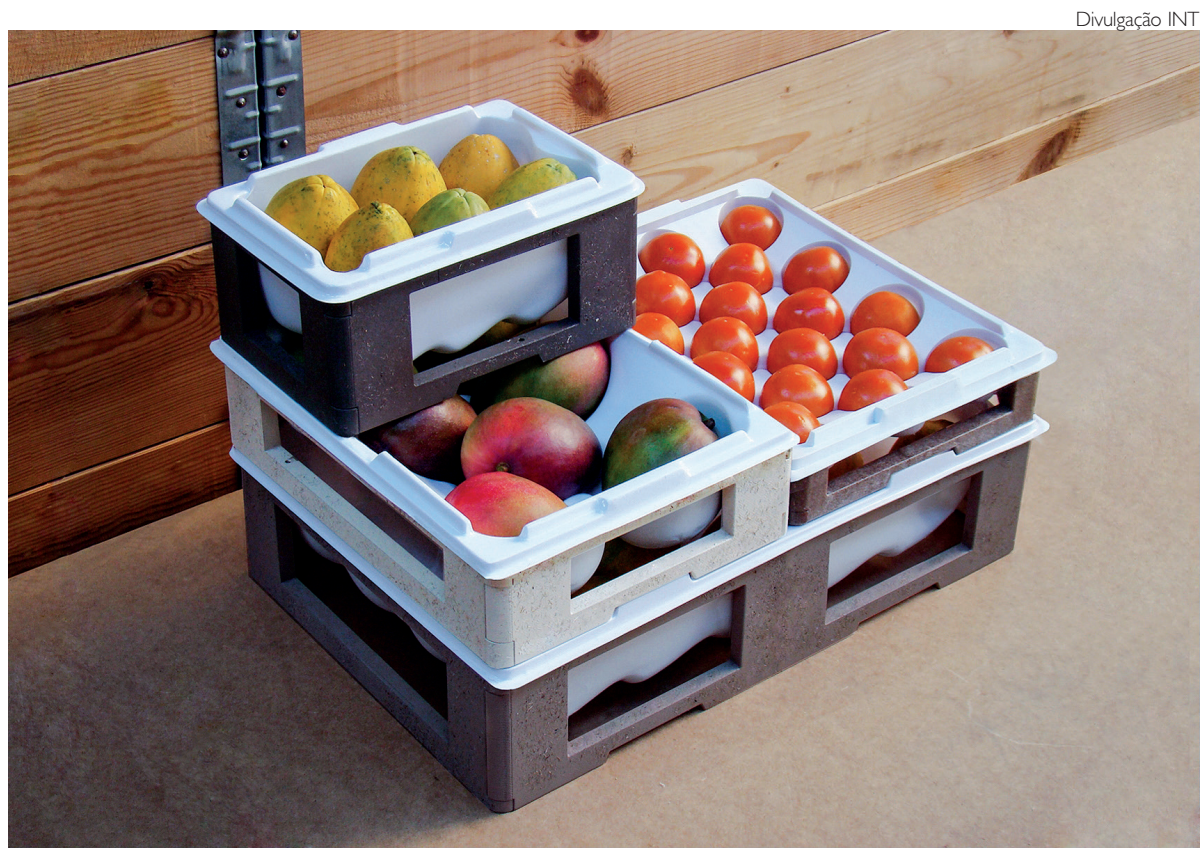

Sem sobreposição, caquis duraram mais no supermercado, reduzindo o desperdício

tas e tenham entrada de ar, importante para prevenir temperaturas mais altas e frear o processo de degradação. As embalagens são articuladas, têm baixo peso, são acopladas a bandejas específicas para cada tipo de fruta e são reutilizadas após a entrega dos produtos. A base é composta por materiais que usam resíduos minerais ou de fibras vegetais, muitas vezes, gratuitos ou de baixo custo, enquanto a bandeja pode ser feita a partir de plástico PET reciclado. Luiz Carlos do Carmo Motta, da Divisão de Desenho Industrial do INT, informa que a base pode ter custo até inferior ao de outras caixas atualmente em uso, além de contribuir para retirar do ambiente resíduos que podem causar impactos ambientais.
O desenho das embalagens considerou as características fisiológicas, organolépticas (cor, textura, sabor, odor etc) de cada fruta, entre as quais o caqui, manga, mamão papaia, morangos e palmito de pupunha processado. "Cada tipo de fruta respira e libera etileno de forma própria. Como as nossas embalagens respeitam estas características essenciais de cada tipo de fruta, elas colaboram para a redução das perdas pós-colheita e aumentam a vida útil dos produtos acondicionados", afirma. De acordo com testes realizados pelo CTAA/ Embrapa, as embalagens reduziram em até $70 \%$ as perdas pós-colheita de caquis, por exemplo.

Germana Barata 